\title{
Mathematical models supporting the monitoring of Civitavecchia harbour (Rome)
}

\author{
S. Bonamano ${ }^{1}$, F. Paladini de Mendoza ${ }^{1}$, V. Piermattei ${ }^{1}$, \\ R. Martellucci ${ }^{1}$, A. Madonia ${ }^{1}$, V. Gnisci ${ }^{1}$, E. Mancini ${ }^{1}$, \\ G. Fersini ${ }^{3}$, C. Burgio ${ }^{3}$, M. Marcelli ${ }^{1} \&$ G. Zappalà ${ }^{2}$ \\ ${ }^{I}$ DEB Experimental Oceanology and Marine Ecology Laboratory, \\ Tuscia University, Italy \\ ${ }^{2}$ Istituto per l'Ambiente Marino Costiero (IAMC), \\ National Research Council, Italy \\ ${ }^{3}$ Port Authority of Civitavecchia-Fiumicino-Gaeta, Italy
}

\begin{abstract}
Knowledge of the sources and types of pollutants, of the hydrodynamic field and of the health status of the marine ecosystems subjected to stress is needed to monitor coastal marine environments. The building of new piers and docks and the extension of a breakwater in Civitavecchia harbour have required extensive dredging that was authorised by the Minister of Environment with the prescription to monitor the coastal marine ecosystems with reference to Posidonia oceanica and benthic biocenoses. The structure of benthic communities and the health status of P. oceanica meadows are important indicators of the Ecological Quality Status of coastal marine waters (WFD, 2000/60/CE). In 2012, a multi-platform observing system (C-CEMS) was tested taking into account: a) the distribution of benthic biocenoses; b) physical and biological data acquired by fixed stations and periodic in situ samplings; and c) the results of numerical simulations of sediment particle tracking. This approach was used along the coastline of Northern Latium (Italy) between Tarquinia and Santa Severa. The dispersion of suspended and deposited materials calculated by numerical model is strongly related to the decrement of the shoots density of P. oceanica and to changes of benthic community's structures. Keywords: dredging activities, numerical model, Posidonia oceanica meadows, soft-bottom benthic communities.
\end{abstract}




\section{Introduction}

The organisms that live in close relationship with the substrate bottom may be affected by an increase of turbidity and sedimentation rate, as well as by the presence of contaminants associated to fine particles of sediments. Up to now few studies have investigated the impacts of dredging on $P$. oceanica meadows [1] and on soft bottom benthic communities [2].

$P$. oceanica is a marine phanerogama used as marine quality status indicator thanks to its sensitivity to environmental changes: if the light available for the photosynthesis is below the $7.8 \%$ of solar surface radiation for a long time, the plants die [3]. Also the increase of sedimentation can lead to bury of apical meristems producing their death [4].

Also the soft bottom benthic communities can be used as direct descriptors of sedimentary imbalances related to dredging operations $[5,6]$. Thanks to a much slower turnover than that of planktonic populations, the benthic communities have the ability to record a longer series of environmental events and can, therefore, provide information on previous disturbances $[7,8]$.

In the last years Civitavecchia harbour has intensified commercial and tourist traffics, increasing the necessity to evolve and expand. For this reason various functional enhancements were approved, in particular the Cristoforo Colombo embankment extension, ferries and services docks realization. The first action concerns the north oriented extension of the embankment and a deepening between the depths of $-29 \mathrm{~m}$ and $-34 \mathrm{~m}$ respect mean sea level, involving the dredging of the channel to access the port of Civitavecchia over an area of approximately $31,000 \mathrm{~m}^{2}$. For the ferry dock area the seabed reaches a depth of $10 \mathrm{~m}$ on an area of approximately $123,650 \mathrm{~m}^{2}$ and $-15 \mathrm{~m}$ over an area of approximately $51,900 \mathrm{~m}^{2}$. The total volume of this dredging, performed between $1^{\text {st }}$ November 2012 and $31^{\text {st }}$ January 2013 , is $918,000 \mathrm{~m}^{3}$.

In this paper the effects of the dredging activities on seagrasses and benthic communities located along the shoreline between Montalto di Castro and Santa Severa (Latium, Italy) are analyzed through the use of the Civitavecchia Coastal Environment Monitoring System (C-CEMS). C-CEMS is an observatory network which collects long-term observations (L-TER), integrating data from land-based stations and buoys with in situ samplings, satellite observations and mathematical models. Previously applied to the study of faecal bacteria dispersion for bathing water quality assessment $[9,10]$, in this investigation C-CEMS was used for the evaluation of benthic ecosystems status exposed to an increase of turbidity and sedimentation.

\section{Materials and methods}

\subsection{The study area}

The study area, located in the west coast of central Italy, is comprised between Santa Severa in the south and Marina di Tarquinia in the north (Fig. 1). 


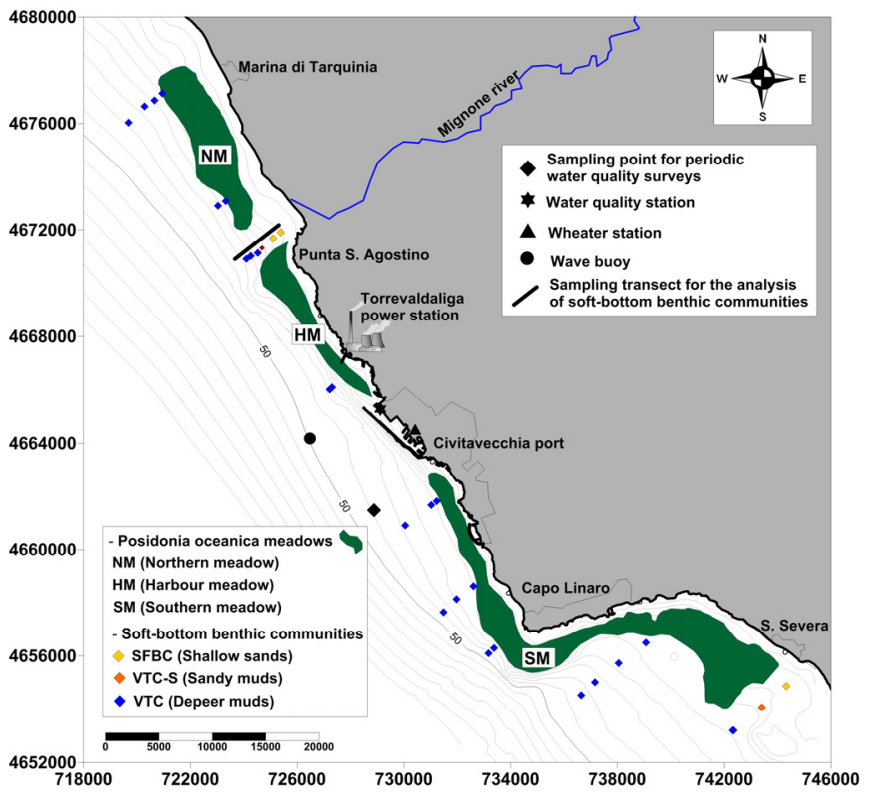

Figure 1: Study area with the sampling point, fixed stations and environmentally sensitive areas.

A synthetic description of $P$. oceanica meadows and soft bottom benthic community structure before dredging activities is reported below.

The harbour environmental conditions were assessed in a previous paper [11].

The $P$. oceanica meadows located northern of Civitavecchia harbour are about $9.65 \mathrm{~km}^{2}$ (Northern Meadow, NM) and $4.46 \mathrm{~km}^{2}$ (Harbour Meadow, HM) of extension. They are located mainly on rocky bottom, with a little presence of matte and dead matte. The meadow located southern of Civitavecchia harbour (Southern Meadow, SM) has a size of $19.84 \mathrm{~km}^{2}$, and sets on rocky and sandy bottom. Soft bottom benthic communities are mainly represented by the SFBC (Shallow sands, [12]) till to about $10 \mathrm{~m}$ of depth, while the VTC-S (Sandy muds) is poorly represented. At depths greater than $10 \mathrm{~m}$, the fine sediment fraction increases and, consequently, the percentage of the limicolous species exceeds the sabulicolous ones. In the southern area VTC (deeper muds) communities are dominant between $10 \mathrm{~m}$ to $50 \mathrm{~m}$ of depth because the seabed is mainly composed by muddy sediment.

\subsection{Description of C-CEMS}

C-CEMS is a multi-platform observing system that operates in the coastal marine area of Civitavecchia (Latium, Italy). It provides integrated information to be used in different fields of the environmental research [10]. In order to evaluate the effects of the dredging activities on the biotic components of coastal marine ecosystem C-CEMS was implemented with the addition of $P$. oceanica meadows and benthic community data as reported in Fig. 2. The up-graded system takes into 
account the following components: 1) a weather, a wave and a water-quality station located in the harbour area of Civitavecchia; 2) data collected during in situ surveys for the analysis of physical, chemical and biological parameters of the water column and the characterization of $P$. oceanica meadow and benthic communities; 3) information on dredging activities and materials; 4) the mathematical models which use the collected datasets to simulate wave and currents conditions as well as the dispersion of conservative or non-conservative particles inside the study area, to assess the effects of dredging activities on $P$. oceanica meadows and the soft-bottom benthic communities within the study area.

In the following sections C-CEMS data acquired during the dredging period (November 2012 - January 2013) are reported.

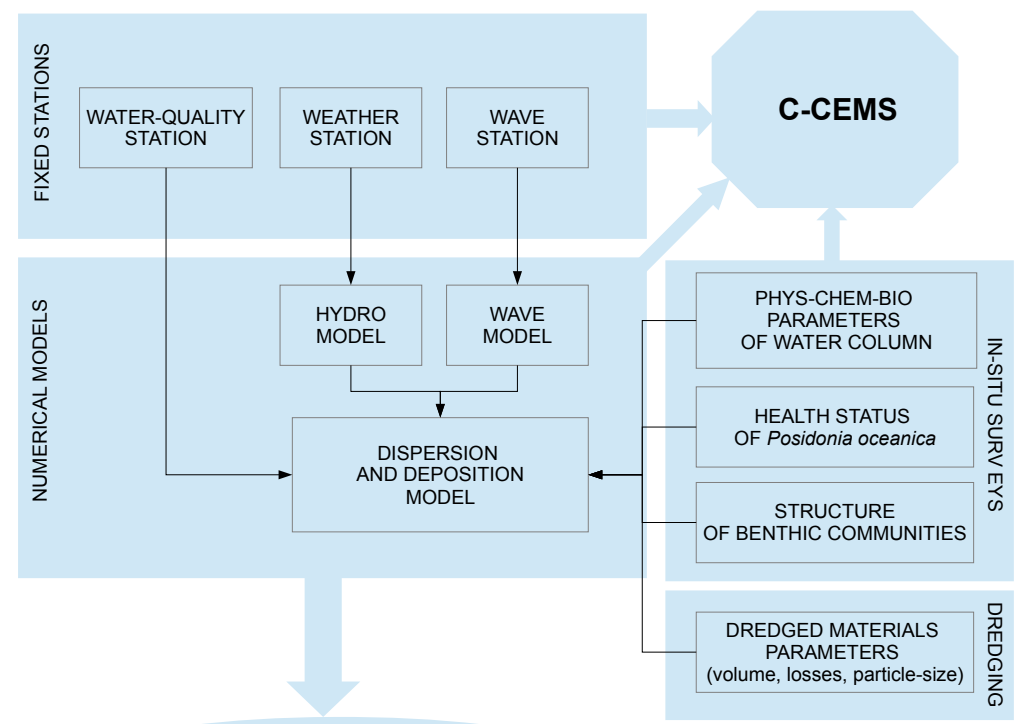

EVALUATION OF POTENTIAL IMPACTS AND SOFT-BOTTOM BENTHIC COMMUNITIES

Figure 2: Scheme of C-CEMS application.

\subsection{Weather and wave data}

The weather station, installed in Civitavecchia harbour in 2007, acquired every 10 minutes air temperature, relative humidity, atmospheric pressure, solar radiation, rain, wind speed and direction. The wave parameters (significant wave height, peak period and mean direction) have been calculated on the basis of the registrations carried out by a wave buoy positioned at 50 meter depth off the port entrance (Lat. $42.097^{\circ} \mathrm{N}$, Long. $011.744^{\circ} \mathrm{E}$ ).

The atmospheric and wave conditions during the dredging period are reported in Fig. 3. 

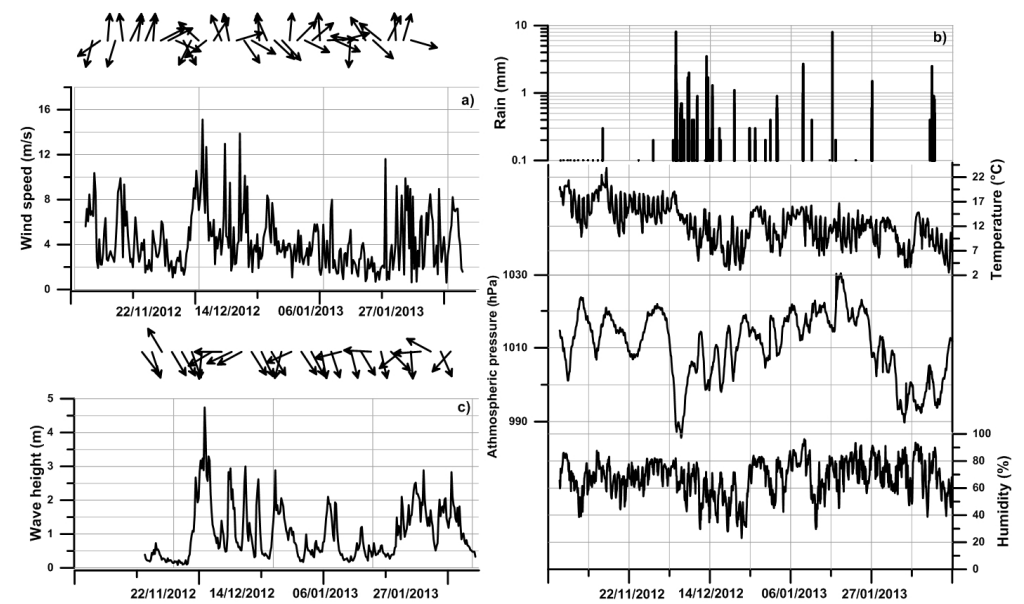

Figure 3: Weather and wave conditions during dredging activities. Vectors in (a) and (c) panels indicate respectively the wind and wave direction.

\subsection{Physical and biological parameters of seawater}

A continuous acquisition of marine physical and biological parameters was carried out through a fixed measuring station and periodic in situ surveys.

The measuring station is installed in the harbour of Civitavecchia and allows the acquisition of temperature, conductivity (salinity, density), dissolved oxygen, $\mathrm{pH}$, turbidity and fluorescence of chlorophyll $a$. Furthermore, a series of oceanographic surveys were carried out between 19/11/2012 and 31/01/2013 using an IDRONAUT 316 plus multiparametric probe.

The physical and biological parameters of seawater during the dredging period are reported in Fig. 4.

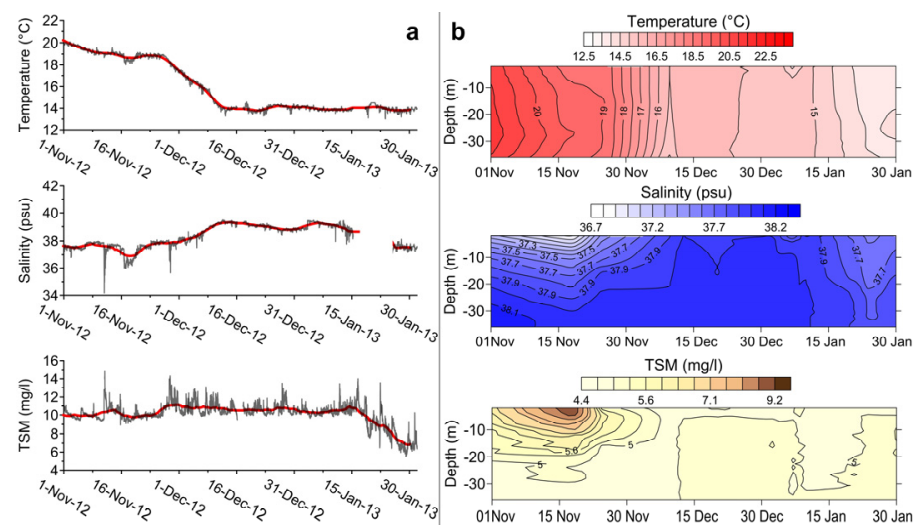

Figure 4: Time series (a) and vertical distribution (b) of temperature, salinity and Total Suspended Matter (TSM) obtained by water quality station and periodic in situ samplings, respectively. 


\subsection{Coastal marine ecosystem}

The surveys to define the health status of $P$. oceanica meadows were performed before and after dredging activities, analyzing structural parameters as the shoots density (number of shoots for square meter).

The shoots densities in three $P$. oceanica meadows located near Civitavecchia Harbour (HM), in the northern (NM) and southern (SM) areas before and after the dredging are compared in Fig. 5. In the northern area (NM) the shoots density has decreased from $277.08 \pm 74.56$ to $188.54 \pm 45.10$ shoots $/ \mathrm{m}^{2}$ after the dredging activities, and so in the southern part (SM) with a decrease from $301.04 \pm 79.77$ to $253.125 \pm 89.16$ shoots $/ \mathrm{m}^{2}$. On the contrary, the meadow located near the dredged areas (HM) shows a little increase in the number of shoots present in the square meadows, from $453.125 \pm 216.55$ to $468.75 \pm 238.69$ shoots $/ \mathrm{m}^{2}$.
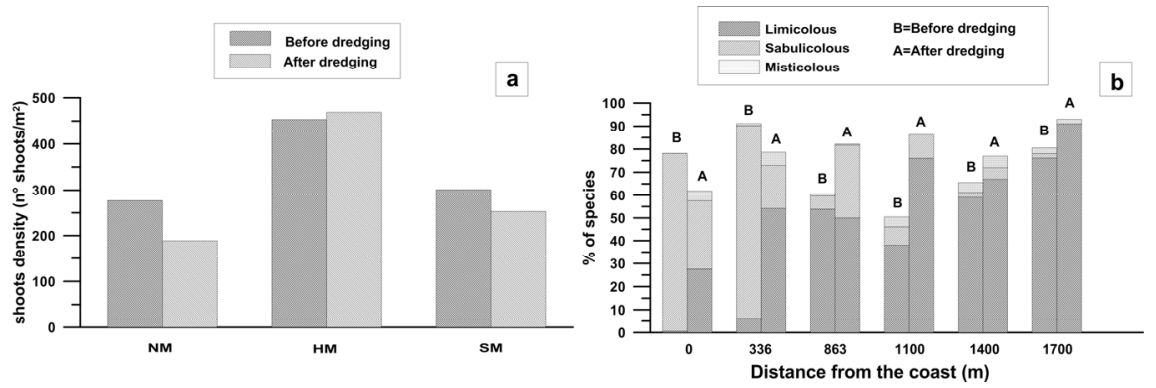

Figure 5: Shoots density in the three $P$. oceanica meadows (a) and trophic groups of soft-bottom benthic communities along the inshoreoffshore transect located in correspondence of Punta S.Agostino (b).

The survey on the soft-bottom benthic communities, carried out after the dredging operations, shows some alterations both in the ecological features of the species and in the distribution of number of individuals, between southern and northern areas. In the first one the species richness is greater than that found northern of Civitavecchia harbour (1222 vs 997) where structural and trophic variations of the communities are higher than those observed before dredging.

In correspondence of Punta S.Agostino, between $10 \mathrm{~m}$ and $20 \mathrm{~m}$ of depth, the indicator-species of SFBC (Shallow sands) have been changed with mud-adapted species (VTC, Sandy muds) as polychaetes Sternaspis scutata and Paraprionospio pinnata, and echinoderms Leptopentacta elongata and Leptopentacta tergestina. In this zone the displacement of VTC limit toward coast determines a strong increase of the mud adapted species, changing from $3.4 \%$ to $40.6 \%$ (Fig. 5(b)). Accordingly, the limicolous and misticolous species increase while the number of sand-adapted ones get down after the dredging operations (from 80.75\% to $24.4 \%$ ). As a result, the pool of the 10 most abundance species in this area is formed by individuals that live in the sandy-muds habitat as polichetes Sternaspis scutata, Paraprionospio pinnata and Lumbrinereis latreilli, echinoderms Amphiura chiajei and Amphiura filiformis, tanaid Apseudes echinatus and bivalves 
Corbula gibba (indicator of sedimentary imbalances) and Nucula nitidosa. Moreover, the increase of mixticolous species (from $0.45 \%$ to $5 \%$ ) as Terebelloides stroemi, Ampharete acutifrons and the echinoderms of the genus Amphiura could be associated to recolonization processes due to sediment-size variations.

\subsection{Hydrodynamical field}

The data collected by C-CEMS have been used as input conditions for the numerical models that simulate marine currents (ADCIRC, [13]), the wave propagation (STWAVE, [14]) and the dispersion of the dredged material (PTM, [15]).

The hydrodynamic field has been obtained by the combined use of ADCIRC and STWAVE models that employ speed and direction of wind measured by weather station and wave parameters (significant wave, peak period and mean direction) acquired with wave buoy. The resulting marine currents feed the PTM model that reproduces transport, deposition and resuspension processes of dredged material on the basis of its size and density and of the physical parameters (temperature and salinity) of the water column.

The dredging activity has been simulated using a point mass rate source located at the harbour entrance and assuming the release of the $963 \mathrm{~kg} / \mathrm{s}$ of fine sediment fraction $(<0.063 \mathrm{~mm})$. This value has been calculated considering the dredging duration (92 days), the total volume $\left(918,000 \mathrm{~m}^{3}\right)$ and the losses related to fine fraction (38\%) of the dredged material [16]. The transport, deposition and resuspension processes associated to the fine particles have been reproduced taking into account a settling velocity of about $0.0005 \mathrm{~m} / \mathrm{s}$, a critical shear for initiation of $0.1 \mathrm{~N} / \mathrm{m}^{2}$ and a critical shear for deposition of $0.075 \mathrm{~N} / \mathrm{m}^{2}$ [17].

From the analysis on intensity-direction distribution applied to wind and wave data acquired during the dredging activity, three main events coming from SouthEast (Scirocco), South-West (Libeccio) and West (Ponente), with frequency of $24 \%, 22 \%$ and $5 \%$ respectively, have been selected as conditions to feed ADCIRC and STWAVE models. Moreover the atmospheric conditions recorded between $26 / 11 / 2012$ and 2/12/2012, considered as representative of the entire period of the dredging activity, have also been used to feed simulation.

The highest intensity of marine currents is recorded during Ponente conditions at Capo Linaro and in correspondence of Torrevaldaliga power station. On the contrary, Libeccio and Scirocco scenarios are characterized by lower currents coming from south. Also between 26/11/2012 and 2/12/2012 the velocity direction is northwards with a decreasing intensity.

Table 1: Summary of the chosen scenarios.

\begin{tabular}{|l|l|l|l|l|l|}
\hline Scenario & $\begin{array}{l}\text { Wind velocity } \\
(\mathrm{m} / \mathrm{s})\end{array}$ & $\begin{array}{l}\text { Wind direction } \\
\left({ }^{\circ} \mathrm{N}\right)\end{array}$ & $\begin{array}{l}\text { Wave height } \\
(\mathrm{m})\end{array}$ & $\begin{array}{l}\text { Wave } \\
\text { direction }\left({ }^{\circ} \mathrm{N}\right)\end{array}$ & $\begin{array}{l}\text { Peak period } \\
(\mathrm{s})\end{array}$ \\
\hline Libeccio & 13.4 & 202 & 2.7 & 230 & 6.75 \\
\hline Scirocco & 7.5 & 2.2 & 157 & 6 \\
\hline Ponente & 11.5 & 1.1 & 290 & 4.5 \\
\hline REAL & \multicolumn{2}{|l|}{ Wind and wave collected between $26 / 11 / 2012$ and $2 / 12 / 2012$} \\
\hline
\end{tabular}


In the zone interested by dredging activity, the marine currents resulting from all simulated scenarios are very low because of the presence of anthropic structures that favour the generation of small eddies of about 200-300 $\mathrm{m}$ in diameter, inside and outside the port entrance. Scirocco and Libeccio conditions induce cyclonic and anticyclonic structures inside and outside the harbour, respectively; while Ponente scenarios favour only the generation of anticyclonic eddies in the inner area of the port.

\section{Results}

\subsection{Dispersion and deposition of dredged sediment}

During the dredging period and in the Scirocco and Libeccio scenarios, the materials released at port entrance have been transported northwards. In the real atmospheric conditions a transition zone located at $-15 \mathrm{~m}$ separating dispersion dominance and sedimentation dominance processes is formed: along the coastal zone, most of the dredged material is suspended in the water column (white dots), while in the off-shore area most of the particles are found on the sea bottom (dark dots).

The southern scenarios are characterized by two accumulation areas: the southern one located between port entrance and Torrevaldaliga power station pier and the northern one near Punta S.Agostino. In the Ponente condition the dredged materials are transported southwards rapidly reaching the southern limit of the study area (S.Severa). Most of the dispersed sediment is accumulated homogeneously in the southern zone but near Capo Linaro the concentration of accumulated materials on the sea bottom decreases drastically due to strong marine currents.

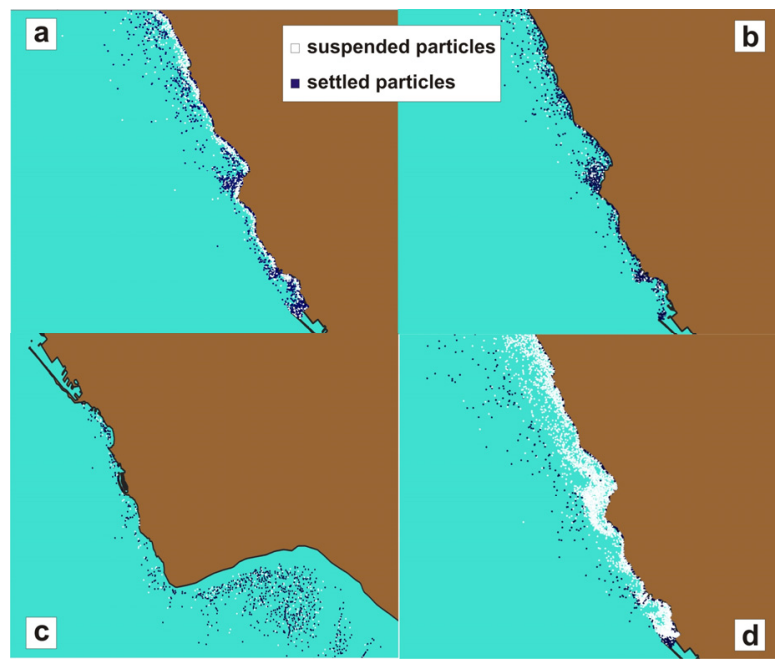

Figure 6: Particles dispersion during Libeccio (a), Scirocco (b), Ponente (c) and REAL (d) scenarios. 


\subsection{Potential effects on Posidonia oceanica and benthic community}

The highest sediment accumulation is found in the zone between the port entrance and Torrevaldaliga power station pier, and in proximity of Punta S.Agostino. In the area near the release point, the dredging activity causes the direct impacts destroying much of the $P$. oceanica meadows located there. In the other impacted zone the increase of dredged fine sediment leads to a strong decrease of the sabulicolous species and an increase of limicolous ones: the benthic community changes from SFBC to VTC. Unlike the Ponente scenario where the high concentration of suspended material is found up to about $800 \mathrm{~m}$ of distance from the coast in the southern part of the study area, in other scenarios the plume of dredged sediments is dispersed northward remaining confined to the shoreline and therefore not producing adverse effects on the $P$. oceanica meadow between Torrevaldaliga power station pier and Punta S.Agostino. The increase of shoots density means that the high turbidity and sedimentation caused by dredging activities do not cause significant impacts on this sensitive area. Conversely, the decrease of shoots of the $P$. oceanica meadow located in the northern part of the study area is probably due to sediment plumes of Mignone and Marta rivers.
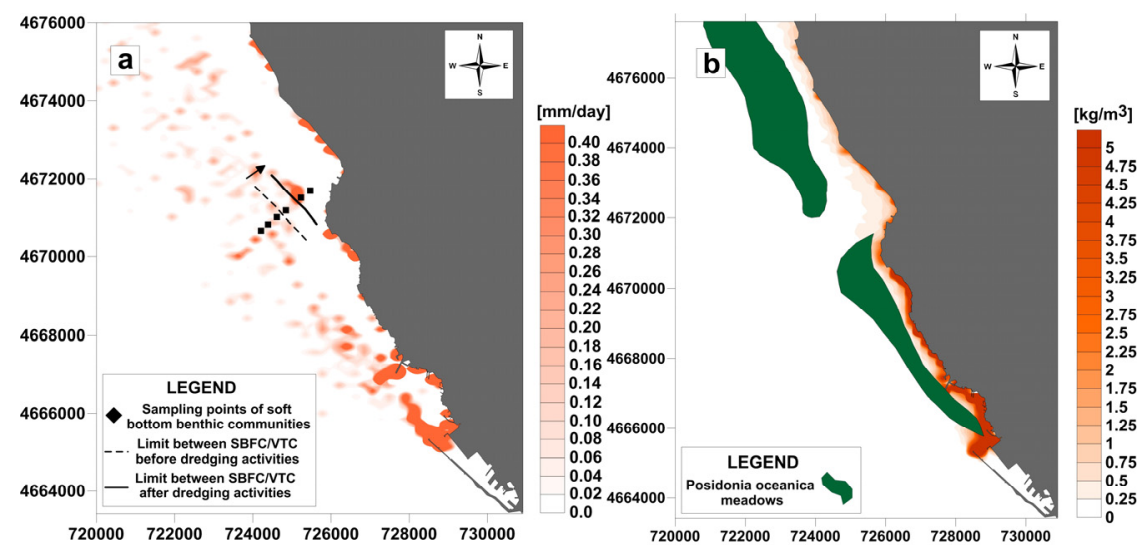

Figure 7: Accumulation (a) and concentration (b) of sediments during the dredging activity.

\section{Discussions and conclusions}

The present study shows that C-CEMS is able to assess the potential impact of the dispersion of fine sediments produced by dredging activities on $P$. oceanica meadows and soft-bottom benthic communities.

The large amount of dredged materials $\left(918,000 \mathrm{~m}^{3}\right)$ and the short operation period (92 days) have favoured a high rate $(963 \mathrm{~kg} / \mathrm{s})$ of dispersed fine sediments that could influence the structure and the health status of this sensitive marine ecosystem. The dispersion of the dredged fine sediments has been detected by water quality station located near the harbour entrance as high values of Total 
Suspended Matter recorded in the entire dredged period. Similarly the physical and biological data collected during the periodic in situ samplings have shown the maximum peak of turbidity on November 26 due to the dispersion of dredged material southwards as a result of wind and wave events coming from the fourth quadrant. This result has been confirmed by the Ponente scenario that shows how the sediment particles released at the port entrance spread quickly southwards causing an extensive zone of high accumulation and concentration of dredged material in the water column. Nevertheless the analysis of wind and wave conditions during the dredging period has highlighted that the southern events (Libeccio and Scirocco) are more frequent than those from the fourth quadrant (Ponente). The potential effects on P. oceanica meadows and soft-bottom benthic community closely depend on Libeccio and Scirocco conditions which also have characterized the Real scenario. The biggest accumulation zones, as resulting from simulations reproducing these scenarios, are inside the dredged area, where the $P$. oceanica shoots have been damaged, and in correspondence of Punta S.Agostino in which the benthic community has changed from SFBC to VTC between $10 \mathrm{~m}$ and $20 \mathrm{~m}$ of depth.

The results of fine material dispersion highlight that the sediment plume arising from dredging is confined within $80 \mathrm{~m}$ from the coast, with higher concentration of suspended sediment near the shoreline than in the offshore zone where $P$. oceanica meadow is found. Also in this case the simulations results are confirmed by the effects produced on the seagrass meadow nearer to the harbour. Although dredging activities leading to increase in turbidity, the shoots density of $P$. oceanica does not decrease, rather increases, changing to 453.125 from 468.75 shoots $/ \mathrm{m}^{2}$.

In the meadow further north, where the concentration of dredged suspended materials is decreasing, the reduction of number of shoot is probably due to the sediment plumes of the Marta and Mignone rivers that flow in the northern zone of the study area.

\section{References}

[1] Capello, M., Cutroneo, L., Ferranti, M.P., Budillon, G., Bertolotto, R.M., Ciappa, A., Cotroneo, Y., Castellano, M., Povero, P., Tucci, S., Simulations of dredged sediment spreading on a Posidonia oceanica meadows off the Ligurian coast, Northwestern Mediterranean. Marine Pollution Bulletin, 79, pp. 196-204, 2014.

[2] La Porta, B., Targusi, M., Lattanzi, L., La Valle, P., Paganelli, D., Nicoletti, L., Relict sand dredging for beach nourishment in the central Tyrrhenian Sea (Italy): effects on benthic assemblages. Marine Ecology, 30 (Suppl. 1), pp. 97-104, 2009.

[3] Gordon, D.M., Grey, K.A., Chase, S.C., Simpson, C.J., Changes to the structure and productivity of a Posidonia sinuosa meadow during and after imposed shading. Aquatic Botany, 47, pp. 265-275, 1994. 
[4] Manzanera, M., Pérez, M., Romero, J., Seagrass mortality due to oversedimentation: an experimental approach. Journal of Coastal Conservation, 4, pp. 67-70, 1998.

[5] Simonini, R., Ansaloni, I., Bonvicini Pagliai, A.M., Cavallini, F., Iotti, M., Mauri, M., Montanari, G., Preti, M., Rinaldi, A., Prevedelli, D., The effect of sand extraction on the macrobenthos of a relict sands area (northern Adriatic Sea), results 12 months post-extraction. Marine Pollution Bulletin, 50, pp. 768-777, 2005.

[6] Marzialetti, S., Gabellini, M., La Porta, B., La Valle, P., Paganelli, M., Targusi, M., Nicoletti, L., Dredging activities for beach nourishment in an area offshore Montalto di Castro (VT): effects on Polychaete community. Biologia Marina Mediterranea, 13(1), pp. 601-605, 2006.

[7] Tenore, K.R., Roman, N.Z., Terwin, J., Andrade, F., Blanton, J., Boynton, W., Carey, D., Diaz, R., Holland, A.F., López-Jamar, E., Montagna, P., Nichols, F., Rosenberg, R., Queiroga, H., Sprung, M., Whitlatch, R.B., Characterizing the role benthos plays in large coastal seas and estuaries: a modular approach. Journal of Experimental Biology and Ecology, 330, pp. 392-402, 2006.

[8] Bedulli, D., Bianchi, C.N., Zurlini, G., Morri, C., Caratterizzazione biocenotica e strutturale del macrobenthos delle coste pugliesi. Rapporti ENEA, pp. 227-255, 1986.

[9] Zappalà, G., Bonamano, S., Madonia, A., Caruso, G., Marcelli, M., Microbiological risk assessment in a coastal marine environment through the use of mathematical models. WIT Transactions on Ecology and the Environment, 164, pp. 3-14, 2012.

[10] Zappalà, G., Caruso, G., Piermattei, V., Bonamano, S., Madonia, A., Di Cicco, A., Marcelli, M., Integrated Marine Measurements in Civitavecchia, near Rome. WIT Transactions on Modelling and Simulation, 55, pp. 221235, 2013.

[11] Zappalà, G., Piermattei, V., Madonia, A., Martellucci, R., Bonamano, S., Pierattini, A., Burgio, C., Marcelli, M., Assessment of environmental conditions in Civitavecchia (Rome, Italy) harbour. WIT Transactions on Ecology and The Environment, 182, pp. 271-282, 2014.

[12] Peres, J.M., Pickard, J., Nouveau manuel de bionomie benthique de le Mer Mediterranee. Recuil des Travaux de la Station Marine d' Endoume, 31 (47): 5-137, 1964.

[13] Luettich, R.A., Westerink, J.J., \& Scheffner, N.W., ADCIRC: An advanced three-dimensional circulation model for shelves, coasts, and estuaries, Report 1: Theory and methodology of ADCIRC-2DDI and ADCIRC-3DL. Technical Report DRP-92-6, U.S. Army Engineer Research and Development Center: Vicksburg, MS, pp. 1-137, 1992.

[14] Smith, J.M., Sherlock, A.R., \& Resio, D.T., STWAVE: Steady-State Spectral Wave Model user's guide for STWAVE Version 3.0, ERDC/CHL SR-01-01, U.S. Army Engineer Research and Development Center: Vicksburg, MS, 2001. 
[15] MacDonald, N.J., Davies, M.H., Zundel, A.K., Howlett, J.D., Lackey, T.C., Demirbilek, Z., \& Gailani, J.Z., PTM: Particle tracking Model; Report 1: Model theory, implementation, and example applications. ERDC/CHL TR06-20, U.S. Army Engineer Research and Development Center: Vicksburg, MS, 2006.

[16] Hitchcock, D.R., \& Drucker, B.R., Investigation of benthic and surface plumes associated with marine aggregates mining in the United Kingdom. Proceedings of Conference on Oceanology International. The global ocean - towards operational oceanography. Spearhead Publications, Surrey Conference Proceedings, 2, pp. 221-284, 1996.

[17] Lackey, T.C., \& Smith, S.J., Application of the Particle Tracking Model To Predict the fate of Dredged Suspended Sediment at the Willamette River. Proceedings Western Dredging Association Twenty-Eighth Annual Technical Conference, St. Louis, MO., USA. 2008. 